\title{
ПРВИ РЕЗУЛТАТИ ЗАШТИТНИХ АРХЕОЛОШКИХ ИСТРАЖИВАЊА НА БЕЛОМ БРДУ У ВИНЧИ 2019. ГОДИНЕ
}

\author{
Кристина Пенезић \\ Универзитет у Новом Саду, Институт Биосенс \\ Дејан Радичевић \\ Одељење за археологију, Филозофски факултет, \\ Универзитет у Београду \\ Јелена Булатовић
}

Лабораторија за биоархеологију, Одељење за археологију, Филозофски факултет, Универзитет у Београду

\section{Ненад Тасић}

Одељење за археологију, Филозофски факултет, Универзитет у Београду

\author{
e-mail: kristina.penezic@biosense.rs \\ Примљено: 27. 7. 2020. УДК: 904:726.8”653”(497.11) \\ Прихваћено: 23. 8. 2020. 902.2(497.11)"2019”
}

\begin{abstract}
Апстракт: У раду су представљени прелиминарни резултати археолошких истраживања обављених 2019. године на делу налазишта које је захваћено клизиштем. Ископавања су извршена на повриини од око $250 \mathrm{M}^{2}$, у ичиьу заштите средњовековне некрополе која представља најфрагилнији део културних слојева у Винчи. На истраженој повриини је документована 91 гробна иелина. Према предметима нађеним у гробовима време сахрағивања оквирно је опредељено у раздобље 13-14. века. На простору некрополе откривени су и остаци три пећи, које су такође приписане средњовековном периоду, али су старије од истражених гробова. Најстарије хоризонте на површини обухваћеној ископавањима чинила су два горела, рушевинска слоја неолитских објеката.
\end{abstract}

Кључне речи: Винча, локалитет Бело брдо, сектор „Клизиште”, заштитна ископавања, средњовековна некропола

\section{Увод}

Током зиме 2010. године на делу налазишта Бело брдо у Винчи уочени су одрони делова профила који су се највероватније догодили као последица крчења растиња на приватним парцелама. Од тренутка када је уклоњено растиње са парцела које се налазе одмах до профила, указале су 
се гомиле грађевинског шута и другог отпада које су заклањале ожиљак од клизишта. У том тренутку било је коначно могуће снимити стање и поставити реперне тачке за мерење тока, смера и брзине клизишта.

Површина овог дела налазишта је нешто мања од $6000 \mathrm{~m}^{2}$. Највећа дужина поменуте зоне износи 155 м (у правцу северозапад-југоисток), а највећа ширина 58 м (у правцу југозапад-североисток), па је склопљен договор да се уместо наставка систематских истраживања на Сектору 2, који је био истраживан између 1998. и 2009. године, спроведу заштитна истраживања на делу терена непосредно угроженог одронима и клизиштем. Чињеница да су слојеви очувани у изворном облику само у првих двадесетак метара у односу на почетак клизишта диктирала је и начин истраживања на овом простору.

\section{Досадашња истраживања сектора „Клизиште”}

Од 2010. године обављене су бројне географске, геолошке и геофизичке анализе и направљена је стратегија заштите још увек стабилног дела налазишта, који се налази непосредно до ожиљка клизишта. Геолошке сонде, детекција електричним резистивитетом, акустичким таласима и георадаром показали су да је отклизали део налазишта поремећен у све три димензије (Тасић 2015).

У периоду 2004-2005. и 2011-2014. године вршена су истраживања на овом делу налазишта. Циљ је био откривање новог профила на налазишту и прикупљање узорака за С14 датовање, спроведено у оквиру пројекта Европског истраживачког савета (ERC) Times of Their Lives (TOTL), којим су руководили Алисдер Витл (Alasdair Whittle) и Алекс Бејлис (Alex Bayliss). Анализа слојева која је том приликом добијена послужила је и за одређивање стратегије истраживања за делове налазишта са најмањом деформацијом културног слоја као и за датовање налаза и објеката на другим деловима налазиша (Tasić i dr. 2016).

Осим ове стратиграфске сонде, на профилу налазишта истражена је под руководством К. Пенезић још једна слична сонда, која је овог пута била лоцирана на самом ожиљку клизишта, удаљена 30 м од старог Васићевог профила (почетка клизишта). На месту ове сонде површина отклизалог дела налазишта је 5 м нижа од још увек стабилног дела терена. Културне слојеве на овом месту смо пратили до здравице - палеоземљишта и алувијалне терасе, на релативној дубини од 6,2 м. Профил који је том приликом добијен и снимљен послужиће за поређење слојева током истраживања отклизалог дела терена. На тај начин биће могуће да се реконструишу дебљине појединих слојева, али и да се у рачунарској симулацији они врате на изворно место. 
Резултати истраживања спроведених у циљу снимања стања локалитета послужила су као убедљиво средство да се надлежним институцијама скрене пажња на угроженост Винче. Захваљујући томе и спремним плановима за спасавање културног добра начињено је неколико значајних корака који су претходили санацији. Након што је интердисциплинарни тим координиран из Републичког завода за заштиту споменика културе саставио „Студију истраживања, заштите и презентације археолошког налазишта Бело брдо у Винчи, 2016. године”, већ маја 2017. је усвојен „Просторни план подручја посебне намене археолошког налазишта Бело брдо" (Сл. гласник РС, број 43/17), који омогућава законске услове за приступање санацији налазишта. Године 2019. Министарство културе и информисања Републике Србије је предложило а Влада донела одлуку да пројекат „Истраживање, заштита и презентација археолошког налазишта Бело брдо у Винчи” добије статус пројекта од капиталног значаја за Републику Србију.

\section{Претходна ископавања средњовековне некрополе: кампање 1978-1983. и 2011. године}

Истраживања средњовековне некрополе су била најобимнија у кампањама од 1978. до 1983. године. Обављена су у Сектору 2, под руководством Гордане Марјановић-Вујовић. У том периоду је отворена површина

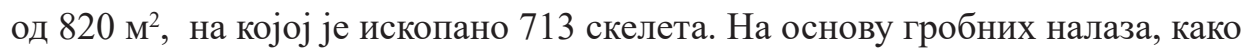
оних пронађених приликом ископавања, тако и старих налаза из збирки Народног музеја у Београду у који су предмети стизали преко откупа и ископавања Милоја М. Васића, поготово у периоду 1911-1912. године, издвојена су четири хоризонта сахрањивања: 1) хоризонт сахрањивања од 8. до 10 . века, 2) хоризонт сахрањивања од 11. до 12. века, 3) хоризонт сахрањивања од 13. до 15. века, 4) хоризонт сахрањивања од 16. до 17. века (МарјановићВујовић 1984, 90-96). На основу увида у теренску документацију са истраживања 1978-1983. године установљено је да су приликом тих радова уочена три хоризонта сахрана, док је четврти, најстарији, углавном издвојен на основу старих налаза из музејске збирке. Иначе, ранија истраживања, како под руководством М. Васића, тако и под руководством Г. Марјановић-Вујовић, указују да је захваћен централни део некрополе, и да се тачно распростирање још увек не може јасно утврдити. За процену распрострањености некрополе користе се подаци о локацијама случајних налаза који су углавном преко откупа доспели у Народни музеј у Београду. Генерално узевши у обзир све ископане скелете, као и мноштво поремећених гробова, долази се до броја од преко 1000 индивидуа сахрањених на Белом брду. 
Истраживања 2011. године била су фокусирана на до тада неистражену површину димензија 4 х 20 м означену као сонда 2011, која се налази неколико метара од Васићевог ископа из 1930. године. Сонда је била оријентисана управно на ток Дунава и вертикални одсек налазишта. Током месец дана теренских радова истражена је и документована 71 гробна целина. Сви скелети су пронађени у опруженом ставу, са приближном оријентацијом запад-исток. Том приликом било је могуће стратиграфски издвојити три хоризонта укопавања, што је одговарало ранијим закључцима о винчанској средњовековној некрополи.

\section{Истраживања 2019. године - методологија и стратиграфске целине}

Последња кампања археолошких ископавања спроведена је од 2. септембра до 15. октобра 2019. године. ${ }^{1}$ Замишљена је као део укупних активности на санацији налазишта. За циљ је имала истраживање најмлађих културних слојева, пре доласка механизације која ће изводити радове на клизишту. Истраживања су спроведена у оквиру квадратне мреже, у комбинацији система стратиграфских целина и контролних ровова (Слика 1). Како би на терену сектора К („Клизиште”) било установљено до које мере су поремећени слојеви, постављена су два контролна рова димензија $1 \mathrm{x}$ 14,5 м (контролни ров 1, оријентисан северозапад-југоисток, паралелан са током Дунава) и 1 х 17 м (контролни ров 2, оријентисан североисток-југозапад, управан на ток Дунава и контролни ров 1). Сонда која је истражена 2011. године зачишћена је и њен северозападни профил је искоришћен у исту сврху - бољи увод у најплићу стратиграфију ископа 2019. године. Тако је добијена јасна слика простирања слојева и у смеру који је паралелан са профилом локалитета ка Дунаву и управно на њега. Истом приликом установљено је и да се средњовековна некропола шири и на овом простору. Димензије сонде истраживане 2019. године износиле су 14,5 м са 17 м.

Овај сектор локалитета је назван „Клизиште” и због очигледне денивелације терена у правцу северозапада (паралелно са Дунавом). За разлику од дела локалитета који је ископаван током 2011. године и који је Музеј града Београда редовно одржавао, на новоотвореној површини први задатак било је уклањање вегетације. Наиме, непосредно до почетка кампање, на овом делу налазишта биле су баште и расадници цвећа. Вишедеценијско коришћење овог дела локалитета у те сврхе, као и редовно засипање

\footnotetext{
${ }^{1}$ Истраживања су спроведена под руководством Ненада Тасића са Одељења за археологију, Филозофског факултета Универзитета у Београду, а средствима Министарства културе и информисања Републике Србије.
} 


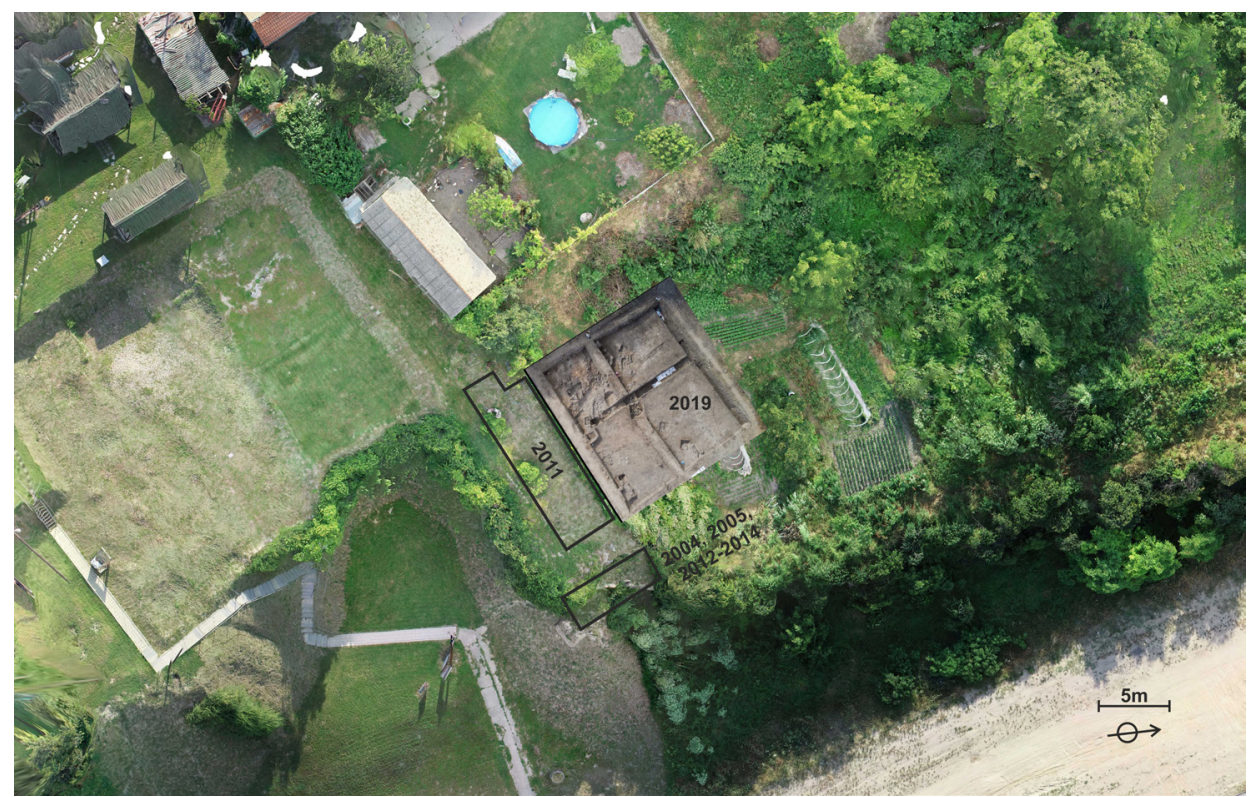

Сл. 1. Поглед из ваздуха на ископ из године 2019. преклопљен на аероснимак локалитета Винча - Бело брдо. Означени су и положаји сонди из 2011. и „стратиграфска сонда” ископавања у периоду 2004, 2005, 2012-2014. године

Fig. 1. Aerial view of the section excavated in 2019, overlapped over the aerial view of the site of Vinča - Belo Brdo. Trenches excavated in 2011 are also marked, as well as the "stratigraphic trench" excavated in the period of year 2004, 2005, 2012-2014

савременим ђубретом и шутом, утицало је и на поремећеност најплићих археолошких слојева. Рецентни материјал је налажен у свим површинским стратиграфским јединицама, некада и до дубине од 0,50 м.

Након уклањања површинског слоја, уочени су многи расцепи и линије пуцања терена услед природног слегања. Ово је довело и до померања скелета и њиховог делимичног или потпуног оштећења. То се најчешће огледало у јасном прелому и недостатку делова скелета, првенствено доњих екстремитета, али понекад и у скоро вертикалном положају делова скелета који су упали у процепе. Дислокације скелета ће бити коришћене као један од елемената за реконструкцију првобитног положаја терена. На очуваност скелета и гробних целина утицало је и дуготрајно и интензивно сахрањивање, због чега су приликом каснијих сахрана често прекопавани старији гробови.

Ископавања су вршена методологијом стратиграфских јединица у оквиру квадратне мреже. Целине у сонди 2011. добијале су бројеве који су се настављали на претходне кампање истраживања, док су стратиграфске јединице у сектору „Клизиште” имале ознаку К испред броја јединице. Сва- 
ка гробна целина је добила ознаку гроба, као и број стратиграфске јединице, док су посебне стратиграфске јединице биле додељене за скелет (у појединим случајевима сваки издвојени скелет у оквиру дефинисаног гроба добио је посебну стратиграфску јединицу, испуну гроба, гробну конструкцију уколико је констатована, итд.). Све тако одређене стратиграфске јединице представљале су једну структуру. На пример, гроб 65/19 састојао се од СЈ К118 (скелет), CJ К117 (испуна гроба) и СJ К121 (део конструкције гроба од секундарно коришћених комада, неолитског горелог лепа). Услед велике оштећености археолошких слојева, нису сви скелетни остаци документовани као гробови. Мањи број артикулисаних људских костију, као и концентрације појединачних костију које су се налазиле између дефинисаних укопа нису добијале ознаке гробова, већ су само биле дефинисане и сакупљене као стратиграфске јединице. На овај начин су документовани и поједини случајеви делова скелета који су проналажени у процепима клизишта, јер није било могуће повезати их са неким од гробова који су и даље били in situ. Услед ових околности, број индивидуа констатованих 2019. године далеко превазилази број дефинисаних гробних целина.

Средњовековни гробови су у потпуности истражени у западном делу сонде 2019. (квадрати 1 и 2), док је у североисточном делу ископа остао део најдубљих слојева сахрана (квадрат 3), а у југоисточном делу (квадрат 4) ископан је само најплићи хоризонт сахрана. Ископавања су вршена до поуздано дефинисаних праисторијских слојева. Дефинисани су рушевински слојеви два неолитска објекта, у југоисточном и југозападном делу ископа.

Колико нам је познато на основу публиковане грађе, као и расположиве теренске документације, новину у односу на сва ранија истраживања овог локалитета представља откриће пећи у северном делу истражене површине. Ради се о остацима три пећи, које су се налазиле на малом међусобном растојању (Слика 2). Откривене су запечене поднице, које су, по свој прилици, припадале калотастим пећима, мада делови калота нису констатовани. Нису уочени ни обриси јама којима се приступало пећима.

Једна од откривених пећи (пећ 3 ) истражена је у целини. Очувана је у приближним димензијама од 0,80 х 0,35 м, јер је делом оштећена укопавањем гроба 87 у њеном североисточном делу (Слика 3). Приликом пресецања ове пећи откривена су два нивоа подница и супструкције, коју су чинили уломци керамичких посуда и делови опека, што сведочи о поправкама и обновама, односно дужој употреби. Фрагменти керамике коришћени у супструкцији припадају посудама које се могу приписати праисторији, али и средњовековном периоду, тако да је јасно да пећ потиче из средњег века. 


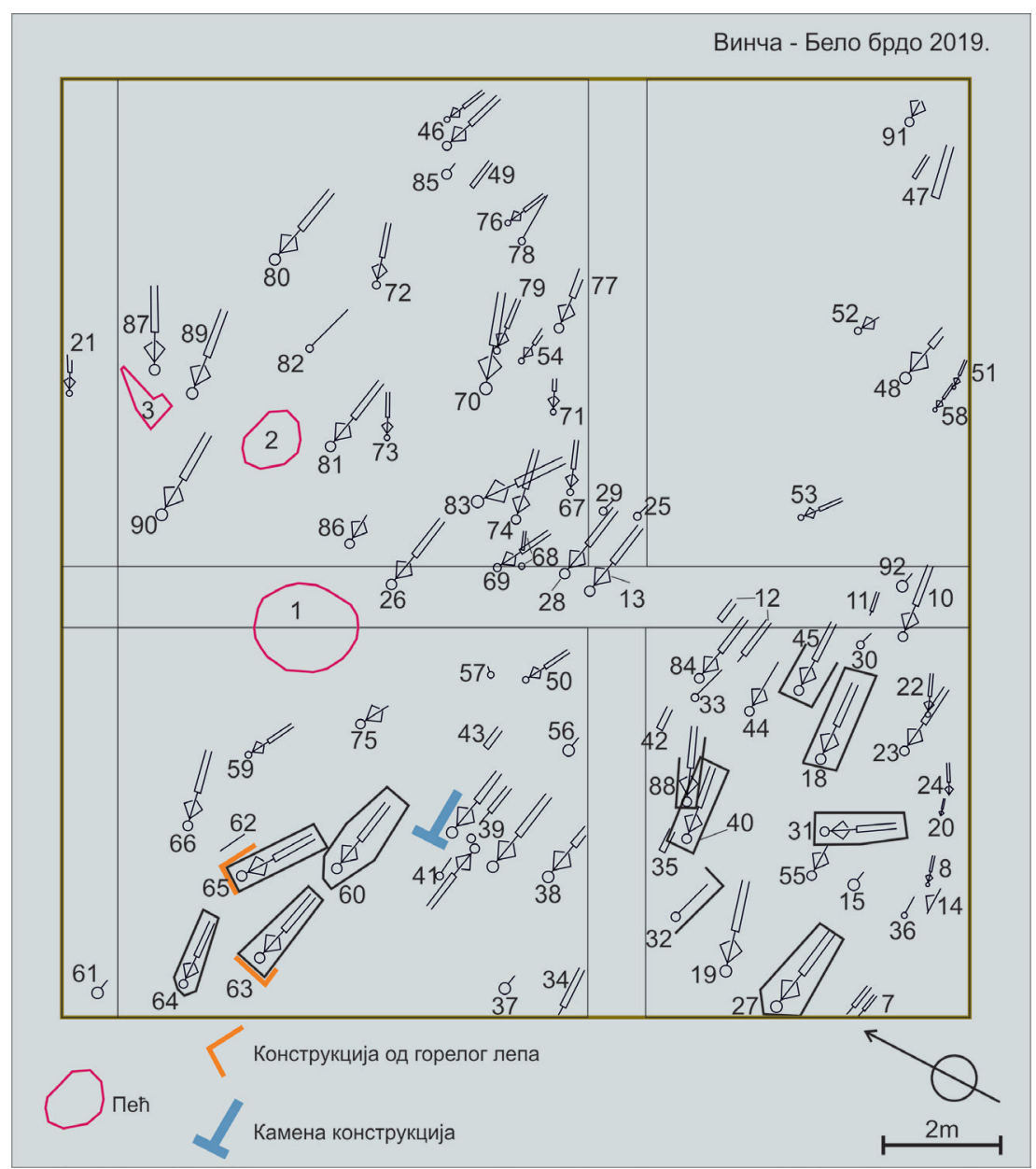

Сл. 2. План ископаних гробова и пећи у сектору К у 2019. години

Fig. 2. Plan of graves and ovens from Sector K, excavated in 2019

Пронађени уломци припадају лонцима израђеним на ручном витлу, од добро пречишћене глине са додатком ситног песка. Боја печења је окер, мрка или тамносива. Већином се ради о деловима трбуха, док су делови рамена и врата заступљени у мањем броју. Мали је и број уломака на којима се види начин украшавања, појасеви таласастих линија урезаних вишеструко назубљеном алатком (чешљем) или таласасте и водоравне линије урезане једноструком алатком. Фрагменти су малих димензија па се не може говорити о облицима посуда, на основу чега би се дао извести поуздан закључак о њиховом хронолошком одређењу. Једино се на основу начина украшавања, првенствено употребе тзв. чешља за урезивање појасева таласастих и 


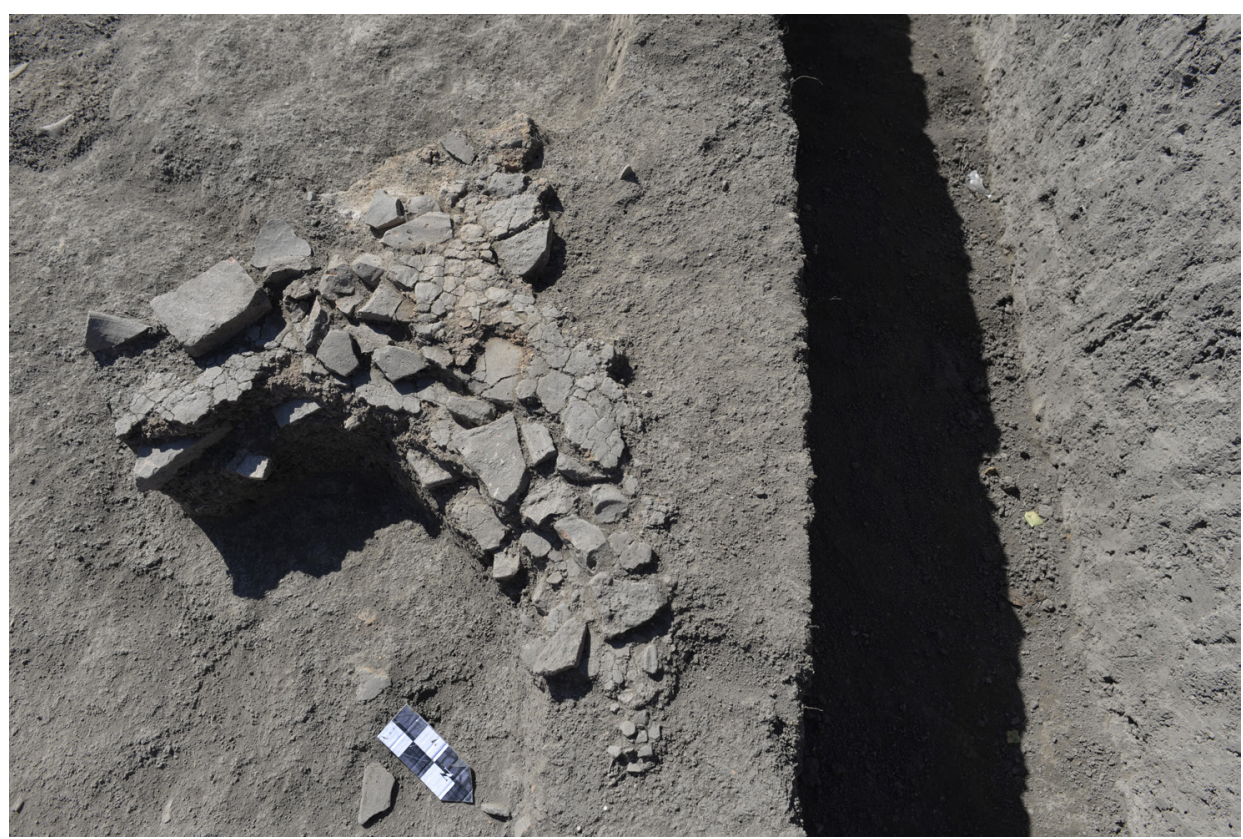

Сл. 3. Пећ 3 истражена 2019. године

Fig. 3. Oven 3, excavated in 2019

водоравних линија, може рећи да се ради о начину украшавања који је карактеристичан за грнчарску производњу Београда са околним подручјем у раздобљу од 9. до 11. века. Грнчарију каква доминира од 12. века одликују промене које се огледају и у новим облицима, и у донекле измењеним старим облицима посуда, али у оба случаја са новим украсима изведеним без употребе чешља (Бикић 1994, 15-20, 40-44; Јанковић 2005, 1-9). Овакав закључак би се поклапао и са запажањима о стартиграфији приликом самих ископавања, према којима откривене пећи претходе укопаним гробовима.

\section{Опис гробних целина}

Укупно је дефинисана 91 гробна целина, а међу њима неке су садржавале и остатке више покојника (Слика 2). Умрли су у највећем броју сахрањивани у једноставне земљане раке. Њихов облик и димензије било је могуће дефинисати само у појединим случајевима, када су се оцртавале у горелом рушевинском слоју неолитских кућа. Гробови су по правилу били без икаквих гробних конструкција. Само у седам случајева уз скелете су се налазили комади опеке, ломљени камен или секундарно коришћени горели леп. Присуство гвоздених клинова и кланфи у пет гробова указује на сахра- 
не у дрвеним конструкцијама/сандуцима, који нису очувани. Оријентација гробова је била у правцу запад-исток, са девијацијама западног дела до око 20 степени ка југу. Изузетак је представљао само један гроб, у коме је покојник сахрањен са главом на истоку, супротно оријентацији свих осталих гробова. Покојници су сахрањивани у опруженом положају, на леђима са главом на потиљку. Руке су по правилу биле положене на трупу или прекрштене на телу.

У оквиру дефинисаних гробних целина забележено је 36 скелета деце и 59 скелета млађих и старијих одраслих индивидуа (Табела 1 у прилогу). ${ }^{2}$ Оно што разликује овај сектор од до сада истраженог дела некрополе јесте присуство дечјих скелета у већем броју него што је то раније забележено. Уз скелетне остатке који су истражени у оквиру гробних целина, на још преко 80 места су сакупљене дислоциране људске кости, било појединачне, било у артикулацији. Овај податак говори у прилог интензивном коришћењу гробља, али и утицају који су на терен имала његова слегања и клизиште, као и савремено коришћење овог дела локалитета од стране мештана.

\section{Налази у гробовима}

Осим поменутих клинова и кланфи, покретни налази су забележени у још седам гробова. На основу појединих налаза може се рећи и нешто одређеније о датовању истражених гробова. Уз лобању покојнице у гробу бр. 10 пронађене су украсне плочице које су некада чиниле саставни део почелице (Слика 4 и Слика 5). Израђене су од танког бронзаног лима, отискивањем на матрици. У угловима имају перфорације, преко којих се ушивају на подлогу од коже или тканине, док се по средини налазе купаста испупчења.

Такве украсне плочице правоугаоног или квадратног облика са једним или више испупчења, израђене од бронзаног и сребрног лима, најчешће су посведочене у функцији почелице, мада су употребљаване и као делови огрлице (Ćorović-Ljubinković 1956, 136-137, fig. 4) или наруквице, а могле су бити коришћене и као украс за одећу или појас (Паровић-Пешикан 1984, 139; Радичевић 2000, 102, Т. II/8). Највећи број налаза ове врсте забележен је у некрополама уз десну обалу Дунава, између ушћа Саве и ушћа Тимока (Bikić 2010, 33-38). Слични налази одраније су већ познати из средњове-

\footnotetext{
${ }^{2}$ Ово је прелиминарна процена вршена на терену током ископавања. Остеолошка анализа хуманог материјала тек предстоји. Антрополошка анализа дечјих скелета је у току у оквиру мастер теме Ане Ћирић у Лабораторији за биоархеологију, Одељења за археологију, као и анализа сахрањивања у оквиру мастер теме Кристине Миљковић на Одељењу за археологију Физолофског факулета, Универзитета у Београду. Повезивање резултата ових анализа са подацима са претходних истраживања средњовековне некрополе (1978-1983) тек предстоји.
} 


\begin{tabular}{|c|c|c|c|}
\hline Број гроба/Grave nr & Број CJ/Unit number & Сектор/Sector & Oпис/Description \\
\hline $1 / 19$ & 2386 & 1 & Одрасла индивидуа/Adult \\
\hline $2 / 19$ & 2392,2393 & 1 & Одрасла индивидуа/Adult \\
\hline $3 / 19$ & 2394 & 1 & Одрасла индивидуа/Adult \\
\hline $4 / 19$ & 2395 & 1 & Дете/Child \\
\hline $5 / 19$ & 2396 & 1 & Одрасла индивидуа/Adult \\
\hline $6 / 19$ & 2397 & 1 & Одрасла индивидуа/Adult \\
\hline $7 / 19$ & $\mathrm{~K} 2$ & $\mathrm{~K}$ & Дете/Child \\
\hline $8 / 19$ & K3 & $\mathrm{K}$ & Дете/Child \\
\hline $9 / 19$ & - & - & Поништен/Annulled \\
\hline $10 / 19$ & $\mathrm{~K} 4, \mathrm{~K} 8, \mathrm{~K} 13$ & $\mathrm{~K}$ & Одрасла индивидуа/Adult \\
\hline $11 / 19$ & K5 & $\mathrm{K}$ & Дете/Child \\
\hline $12 / 19$ & K6 & $\mathrm{K}$ & Одрасла индивидуа/Adult \\
\hline $13 / 19$ & K7 & $\mathrm{K}$ & Одрасла индивидуа/Adult \\
\hline $14 / 19$ & K12 & $\mathrm{K}$ & Дете/Child \\
\hline $15 / 19$ & K15 & $\mathrm{K}$ & Одрасла индивидуа/Adult \\
\hline $16 / 19$ & 2399 & 1 & Одрасла индивидуа/Adult \\
\hline $17 / 19$ & 2400 & 1 & Одрасла индивидуа/Adult \\
\hline $18 / 19$ & K16, K17 & $\mathrm{K}$ & Одрасла индивидуа/Adult \\
\hline $19 / 19$ & K18, K19 & $\mathrm{K}$ & Одрасла индивидуа/Adult \\
\hline $20 / 19$ & $\mathrm{~K} 20$ & $\mathrm{~K}$ & Дете/Child \\
\hline $21 / 19$ & K21 & $\mathrm{K}$ & Дете/Child \\
\hline $22 / 19$ & $\mathrm{~K} 22, \mathrm{~K} 23$ & $\mathrm{~K}$ & Дете/Child \\
\hline $23 / 19$ & $K 24,25$ & $\mathrm{~K}$ & Одрасла индивидуа/Adult \\
\hline $24 / 19$ & K26 & $\mathrm{K}$ & Дете/Child \\
\hline $25 / 19$ & $\mathrm{~K} 27, \mathrm{~K} 30$ & $\mathrm{~K}$ & Дете/Child \\
\hline $26 / 19$ & K34 & $\mathrm{K}$ & Одрасла индивидуа/Adult \\
\hline $27 / 19$ & K36 & $\mathrm{K}$ & Дете/Child \\
\hline $28 / 19$ & K38 & $\mathrm{K}$ & Одрасла индивидуа/Adult \\
\hline $29 / 19$ & K39 & $\mathrm{K}$ & Одрасла индивидуа/Adult \\
\hline $30 / 19$ & K41 & $\mathrm{K}$ & Дете/Child \\
\hline $31 / 19$ & K42, K43 & $\mathrm{K}$ & Одрасла индивидуа/Adult \\
\hline $32 / 19$ & $\mathrm{~K} 44, \mathrm{~K} 45$ & $\mathrm{~K}$ & Дете/Child \\
\hline $33 / 19$ & K46, K47 & $\mathrm{K}$ & Дете/Child \\
\hline $34 / 19$ & K48, K49 & $\mathrm{K}$ & Одрасла индивидуа/Adult \\
\hline $35 / 19$ & K50, K51 & $\mathrm{K}$ & Одрасла индивидуа/Adult \\
\hline $36 / 19$ & K53 & $\mathrm{K}$ & Дете/Child \\
\hline $37 / 19$ & K54 & $\mathrm{K}$ & Одрасла индивидуа/Adult \\
\hline $38 / 19$ & $\mathrm{~K} 55, \mathrm{~K} 56$ & $\mathrm{~K}$ & Одрасла индивидуа/Adult \\
\hline $39 / 19$ & $\mathrm{~K} 58, \mathrm{~K} 59, \mathrm{~K} 60, \mathrm{~K} 82, \mathrm{~K} 83, \mathrm{~K} 84$ & $\mathrm{~K}$ & 4 одрасле индивидуе/4 Adults \\
\hline $40 / 19$ & $\mathrm{~K} 61, \mathrm{~K} 62, \mathrm{~K} 63$ & $\mathrm{~K}$ & Одрасла индивидуа/Adult \\
\hline $41 / 19$ & K64 & $\mathrm{K}$ & Одрасла индивидуа/Adult \\
\hline $42 / 19$ & K65, K 66 & $\mathrm{~K}$ & Одрасла индивидуа/Adult \\
\hline $43 / 19$ & K57 & $\mathrm{K}$ & Дете/Child \\
\hline $44 / 19$ & $\mathrm{~K} 70, \mathrm{~K} 71$ & $\mathrm{~K}$ & Одрасла индивидуа/Adult \\
\hline $45 / 19$ & $\mathrm{~K} 72, \mathrm{~K} 73$ & $\mathrm{~K}$ & Одрасла индивидуа/Adult \\
\hline $46 / 19$ & $\mathrm{~K} 74, \mathrm{~K} 75, \mathrm{~K} 76$ & $\mathrm{~K}$ & Одрасла и дете/Adult and child \\
\hline
\end{tabular}




\begin{tabular}{|c|c|c|c|}
\hline Број гроба/Grave nr & Број CJ/Unit number & Сектор/Sector & Oпис/Description \\
\hline $47 / 19$ & K77, K78, K79 & K & Одрасла и дете/Adult and child \\
\hline $48 / 19$ & $\mathrm{~K} 80, \mathrm{~K} 81$ & K & Одрасла индивидуа/Adult \\
\hline $49 / 19$ & $\mathrm{~K} 85, \mathrm{~K} 86$ & $\mathrm{~K}$ & Одрасла индивидуа/Adult \\
\hline $50 / 19$ & $\mathrm{~K} 87, \mathrm{~K} 88, \mathrm{~K} 89$ & $\mathrm{~K}$ & Дете/Child \\
\hline $51 / 19$ & $\mathrm{~K} 90$ & $\mathrm{~K}$ & Дете/Child \\
\hline $52 / 19$ & K92, K93, K94 & $\mathrm{K}$ & Дете/Child \\
\hline $53 / 19$ & K95, K96 & $\mathrm{K}$ & Дете/Child \\
\hline $54 / 19$ & K97, K98 & $\mathrm{K}$ & Одрасла индивидуа/Adult \\
\hline $55 / 19$ & K99, K100 & $\mathrm{K}$ & Одрасла индивидуа/Adult \\
\hline $56 / 19$ & K68 & $\mathrm{K}$ & Дете/Child \\
\hline $57 / 19$ & K102 & $\mathrm{K}$ & Одрасла индивидуа/Adult \\
\hline $58 / 19$ & K103, K107 & $\mathrm{K}$ & Дете/Child \\
\hline $59 / 19$ & K104, K105 & $\mathrm{K}$ & Дете/Child \\
\hline $60 / 19$ & K110, K111 & $\mathrm{K}$ & Одрасла индивидуа/Adult \\
\hline $61 / 19$ & $\mathrm{~K} 28$ & $\mathrm{~K}$ & Одрасла индивидуа/Adult \\
\hline $62 / 19$ & K112 & $\mathrm{K}$ & Одрасла индивидуа/Adult \\
\hline $63 / 19$ & K113, K114 & $\mathrm{K}$ & Одрасла индивидуа/Adult \\
\hline $64 / 19$ & K115, K116 & $\mathrm{K}$ & Одрасла индивидуа/Adult \\
\hline $65 / 19$ & $\mathrm{~K} 117, \mathrm{~K} 118, \mathrm{~K} 121$ & $\mathrm{~K}$ & Одрасла индивидуа/Adult \\
\hline $66 / 19$ & K119, K120 & $\mathrm{K}$ & Одрасла индивидуа/Adult \\
\hline $67 / 19$ & K123 & $\mathrm{K}$ & Дете/Child \\
\hline $68 / 19$ & K124 & $\mathrm{K}$ & Дете/Child \\
\hline $69 / 19$ & K126, K127 & $\mathrm{K}$ & Дете/Child \\
\hline $70 / 19$ & K128, K129 & $\mathrm{K}$ & Одрасла индивидуа/Adult \\
\hline $71 / 19$ & K132, K133 & K & Дете/Child \\
\hline $72 / 19$ & K134, K135 & $\mathrm{K}$ & Дете/Child \\
\hline $73 / 19$ & K136, K137 & $\mathrm{K}$ & Дете/Child \\
\hline $74 / 19$ & K139, K140 & $\mathrm{K}$ & Дете/Child \\
\hline $75 / 19$ & K141, K142 & $\mathrm{K}$ & Одрасла индивидуа/Adult \\
\hline $76 / 19$ & K143, K144 & $\mathrm{K}$ & Дете/Child \\
\hline $77 / 19$ & K147, K148 & $\mathrm{K}$ & Одрасла индивидуа/Adult \\
\hline $78 / 19$ & K150, K151 & $\mathrm{K}$ & Дете/Child \\
\hline $79 / 19$ & K152, K153 & $\mathrm{K}$ & Дете/Child \\
\hline $80 / 19$ & K154, K155 & $\mathrm{K}$ & Одрасла индивидуа/Adult \\
\hline $81 / 19$ & K156, K157 & $\mathrm{K}$ & Одрасла индивидуа/Adult \\
\hline $82 / 19$ & K158, K159 & $\mathrm{K}$ & Дете/Child \\
\hline $83 / 19$ & K160, K161 & $\mathrm{K}$ & Одрасла индивидуа/Adult \\
\hline $84 / 19$ & K162, K163 & $\mathrm{K}$ & Одрасла индивидуа/Adult \\
\hline $85 / 19$ & K165, K166 & $\mathrm{K}$ & Одрасла индивидуа/Adult \\
\hline $86 / 19$ & K169, K170 & $\mathrm{K}$ & Одрасла индивидуа/Adult \\
\hline $87 / 19$ & K177, K178 & $\mathrm{K}$ & Одрасла индивидуа/Adult \\
\hline $88 / 19$ & K179, K180 & $\mathrm{K}$ & Одрасла индивидуа/Adult \\
\hline $89 / 19$ & K181, K182 & $\mathrm{K}$ & Одрасла индивидуа/Adult \\
\hline $90 / 19$ & K183, K184 & $\mathrm{K}$ & Одрасла индивидуа/Adult \\
\hline $91 / 19$ & K185 & K & Одрасла индивидуа/Adult \\
\hline
\end{tabular}

Табела 1. Списак документованих гробних целина на локалитету Винча - Бело брдо у кампањи 2019. године

Table 1. List of documented grave units at the site of

Vinča - Belo Brdo during the 2019 campaign 


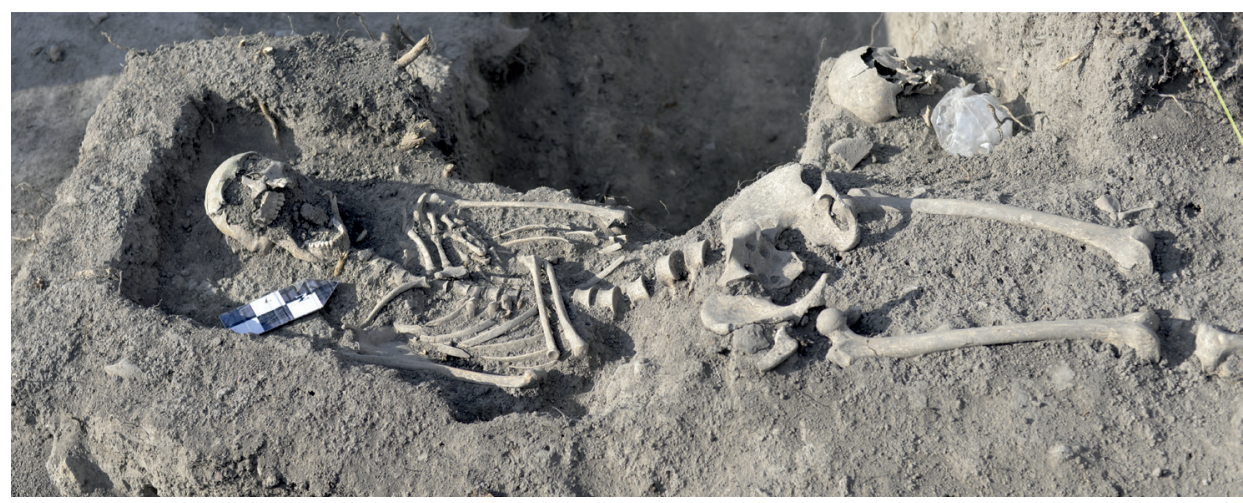

Сл. 4. Гроб 10

Fig. 4. Grave 10

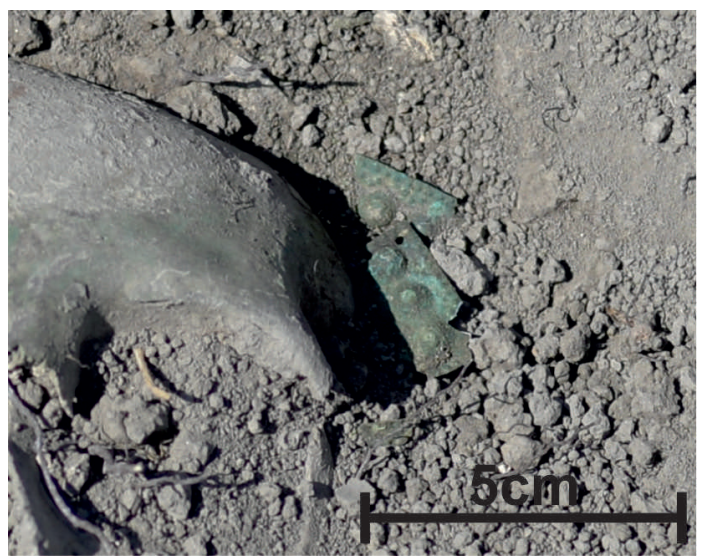

Сл. 5. Гроб 10, детаљ налаза лимених плочица in situ

Fig. 5. Grave 10, a detail of bronze tin applications found in situ

ковних гробова у Винчи. Публиковани су примерци квадратног облика и са по једном калотом у средини (Marjanović-Vujović 1979, Y 211/1), док се међу налазима помињу и украсне плочице са два или три испупчења, али ти примерци још увек нису публиковани (Марјановић-Вујовић 1984, 133). Територијално најближе аналогије овим примерцима налазимо у Миријеву и Брестовику (Бајаловић-Бирташевић 1960, 28, Т. XIV/6; Ђоровић-Љубинковић 1958, 329, сл. 2; Ćorović-Ljubinković 1956, 137, Fig. 4).

Употреба почелица од украсних плочица на налазиштима у Србији оквирно је временски опредељена у раздобље од краја 12. па до у 14. век (Bikić 2010, 36; Ерцеговић-Павловић 1979, 279-282; Марјановић-Вујовић 1985, 6-7). Налази уз десну обалу Дунава низводно од Београда углавном 
се могу датовати у раздобље друге половине 13-14. века (Радичевић 2008, 203-209). Колико нам је познато, једини гробни налаз датован новцем представљају плочице из гроба бр. 7 у Љубичевцу, пронађене заједно са новцем искованим крајем 12. или почетком 13. века, на основу чега је време сахране опредељено у 13. столеће (Radosavljević-Krunić 1986, 331-332).

Поред лобање скелета сахрањеног у гробу бр. 39 пронађен је један римски новчић, који је највероватније секундарно употребљен у функцији обола. Традиција прилагања обола у средњовековним гробовима добро је позната, а осим курентног средњовековног новца прилаган је и старији римски новац. Та је појава већ уочена у српском Подунављу, у гробовима из зрелог и позног средњег века. Наводимо примере из Песаче, Рибнице, Великог Градца, код ушћа Поречке реке и Љубичевца (Минић 1970, 247; Минић 1984, 174-175; Радичевић 2004, 163).

У истом гробу, али у земљи којом је скелет био засут, пронађен је и један каури пуж. Очигледно потиче из старијег гроба поремећеног приликом касније сахране. Присуство каури пужева у гробовима северно од Саве и Дунава региструје се још од 10/11. века (Станојев 1989, 133; Шпехар, Стругар Бевц 2016, 86), док су на десној страни Дунава углавном посведочени у гробовима датованим у 12. и 13. столеће (Марјановић-Вујовић $1984 \mathrm{a}$, 74, T VI/80, T IX/129, T XII/165, T XVIII/273, T. XXI/2 78, T XXII/308; Фидановски, Зечевић 2006, 74-75, Т. II, гроб 8/3; T. IV, гроб 16/2; Т. V, гроб 19/2). Појава каури пужева као саставних делова ниски може се протумачити и само као мода одређеног времена, мада су њима од давнина придавана и посебна својства, од којих су најзначајнија - плодност и богатство, а мислило се да представљају и успешну заштиту од урока (Birtašević 1973, 183-187).

У пределу карлице покојника сахрањеног у гробу бр. 46 пронађена је гвоздена алка. И овај налаз има аналогије са другим некрополама у српском Подунављу, где се појава сличних алки углавном може протумачити у функцији завезивања појаса. У Бољетину су, у пределу појаса покојника у гробу бр. 70, пронађене две бронзане алке (Ерцеговић-Павловић 1986, 29, сл.7, 11-13), док је у Великом Градцу, у гробу бр. 96, такође у пределу поjaca, пронађена једна. Гвоздене алке су пронађене и у Песачи и Хајдучкој Воденици (Ерцеговић-Павловић 1986: 71-77; Минић 1984, 174).

Свакако најзначајнији налаз у кампањи из 2019. године пронађен је у гробу бр. 77, где су, у пределу карлице, откривени делови појаca: копча, гајка и већи број украсних апликација (Слика 6 и Слика 7). Генерално узевши, налази средњовековних појасних гарнитура на нашој територији веома су ретки, тако да, када је реч о расположивој грађи у 


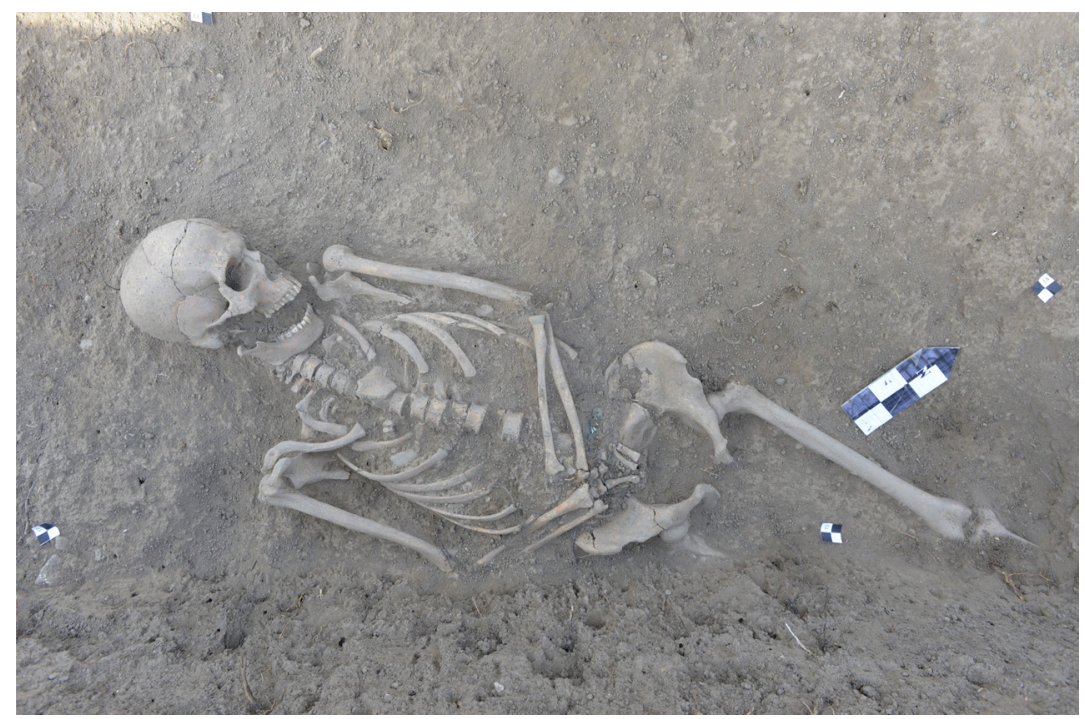

Сл. 6. Гроб 77

Fig. 6. Grave 77

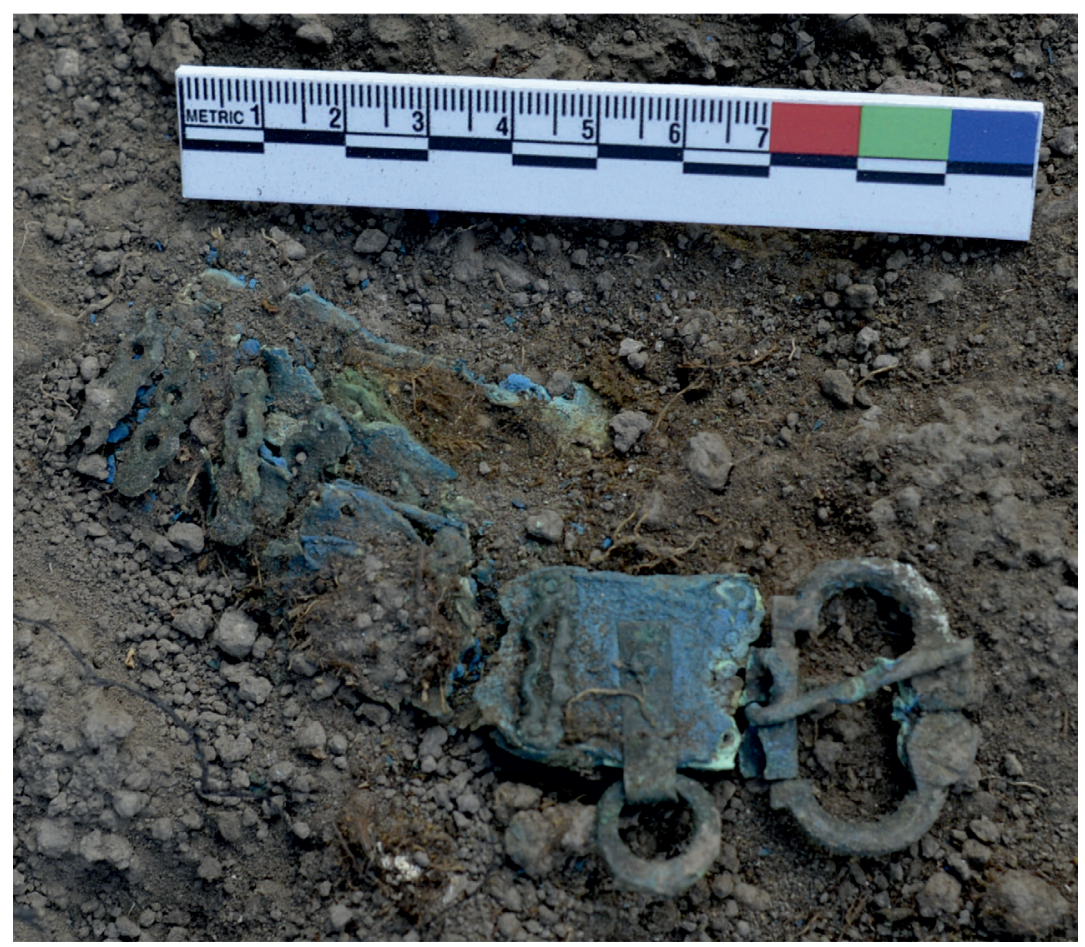

Сл. 7. Гроб 77, детаљ појаса in situ

Fig. 7. Grave 77, a detail of a bronze belt found in situ 
окружењу, овај налаз засад можемо прибројати само појасевима из Томашевца (Brmbolić 1996, 273-277), Петровчића (Станојев 1989, 91-93), или на југу нешто удаљенијег Липовца код Алексинца, одакле потиче засад још увек једина комплетно очувана појасна гарнитура са простора средњовековне Србије (Поповић 2002, 157-177).

Део појаса из гроба бр. 77, на основу кога се може рећи и нешто одређеније у погледу његовог датовања, чинила је пређица у облику латиничног слова „D”, која је била саставни део копчи са правоугаоним оковом за који је везана шарнир механизмом. Њена спољна страна, на коју се ослањао трн, ојачана је кружно обликованим додацима. Према типолошким одликама може се уврстити у групу малих пређица са алком у облику латиничног слова „D”, чија је предња страна ојачана пластичним додацима. Таквим пређицама се приписује западно порекло, а у расположивој грађи са наше територије припадају им пређица из гроба 11 некрополе у Белој Цркви код Крупња (Гарашанин и Гарашанин 1958, 34, сл. 12б), као и пређица из гроба 36 некрополе у Љубичевцу (Radosavljević-Krunić 1986, 335, figs. 3/5, 4/15). У оба случаја су нађене у пределу карлице покојника, што јасно упућује на њихову намену. На Западу се такве пређице датују у раздобље 13. и прве половине 14. века, што би одговарало и примерцима са територије Србије (Радишић 2014, 113-114).

\section{Остаци животиња са ископавања 2019. године}

Током ископавања 2019. године на истраженом простору укупно је било прикупљено 4.980 остатака животиња. Већина фрагмената (4.454) пронађена је на простору клизишта (сектор К), а преостали део (526) потиче из зачишћавања сонде 2011. Међу животињским остацима, идентификовано је укупно и 50 фрагментованих људских костију, од којих су, изузев једне из сонде 2011, све преостале пронађене на простору сектора К. У зависности од тога да ли је археозоолошки материјал потицао са простора сектора К или сонде из 2011, примењен је различит методолошки приступ у његовој обради. На простору сектора К, археолошке стратиграфске јединице, у којима су пронађени остаци животиња, у огромној мери биле су поремећене дејством клизишта и савременим пољопривредним активностима становника Винче, као и (рецентним) покопавањем угинулих домаћих животиња. Наиме, на овом простору откривено је више од десет рецентних целих или делимично очуваних скелета домаћих животиња - свиња, паса и кокошака. С обзиром на то да је највећи број остатака животиња из сектора К потицао из површинских стратиграфских јединица које су биле најоштећеније 
(а мешање рецентног и археолошког материјала у њима најинтензивније), а да је и преостали (мањи) део потицао из такође поремећених целина, на њима није спроведена детаљна археозоолошка анализа. Остаци животиња који су пронађени на простору сектора К само су разврстани по класама (на оне од - сисара, птица, риба, пужева, итд.), пребројани су и идентификовани до најмање могуће таксономске категорије, чиме је завршена њихова анализа. ${ }^{3}$ Услед мешања археозоолошког материјала у овим поремећеним стратиграфским јединицама сектора К, спровођење контекстуалне анализе није било од релевантног значаја.

\section{Закључак}

Део локалитета Винча - Бело брдо је услед деловања клизишта и вишедеценијског коришћења од стране мештана села Винча угрожен. Године 2019, као први корак у припремању санације клизишта на локалитету, спроведена су заштитна ископавања. Установљено је да се средњовековна некропола распростире и на овом делу налазишта. Документовано је преко 90 гробних целина, а у некима од њих било је и четири покојника. За разлику од претходних истраживања некрополе (у периоду 1978-1983, као и 2011. године) уочен је већи број сахрана млађих индивидуа. Покретни археолошки материјал из гробних целина указује на период сахрањивања током 13. и 14. века. Новину у односу на ранија истраживања представља откриће средњовековних пећи старијих од гробова. Само је Пећ 3 истражена у целини. Констатовано је да је подница ове пећи обнављана и да су том приликом као њена супструкција употребљени и фрагменти керамичких посуда, који оквирно могу бити датовани у период од 9. до 11. века. Детаљна анализа како стратиграфије тако и покретног материјала из периода средњег века тек предстоји, али и прелиминарни резултати указују на нове појаве које нису уочене на другим деловима овог налазишта. Ископавања су заустављена на нивоу горелих објеката од лепа из неолитског периода. Детектована су два одвојена горела објекта, у која су делом били укопани покојници.

\footnotetext{
${ }^{3} \mathrm{C}$ друге стране, остаци животиња из јасних (праисторијских) стратиграфских јединица са простора сонде 2011. детаљније су анализирани. Њихова идентификација спроведена је помоћу остеолошких атласа и приручника (нпр. Boessneck 1969; Halstead et al. 2002; Prummel 1988; Prummel and Frisch 1986; Schmid 1972). Код сваког појединачног остатка сисара идентификованог до нивоа рода или врсте, бележене су следеће информације о очуваном делу скелетног елемента и дијагностичким зонама (Dobney and Reilly 1988), симетрији, фрагментацији, степену сраслости епифиза посткранијалног скелета, избијању/трошењу зуба (Grant 1982; Рayne 1973), полу, траговима тафономских процеса (услед горења, глодања, распадања (Behrensmeyer 1978)), модификацијама (услед касапљења, обраде, употребе) и патолошким променама. Мерење костију спроведено је према А. Дриш (Driesch 1976).
} 
Генерално узевши, у потпуности је потврђен интензитет коришћења овог простора, како у праисторијском тако и у средњовековном периоду. Мада угрожен клизиштем и сектор К је указао како локалитет Винча - Бело брдо, након више од века истраживања, и даље крије нова изненађења и заслужује пуну пажњу истраживача.

Захвалница: Јелена Булатовић се захваљује Настасији Радовановић за помоћ при обради археозоолошког материјала са ископавања 2019. године на налазишту Винча - Бело брдо.

\section{БИБЛИОГРАФИЈА}

Бајаловић-Бирташевић, М. 1960. Средњовековна некропола у Миријеву, Београд: Музеј града Београда.

Behrensmeyer, A. 1978. Taphonomic and ecological information from bone weathering. Paleobiology 4, 150-162.

Бикић, В. 1994. Средњовековна керамика Београда, Београд: Археолошки институт. Bikić V. 2010. Vizantijski nakit u Srbiji. Modeli i nasleđe. Beograd: Arheološki institut.

Birtašević, M. 1973. Emploi des coquillaqes cauris dans la parrure médiévale et conttemporaine sur la teritorie de la Yugoslavie, in Berichte über den II Internationalen Kongres für Slavische Archäologie, Berlin 24-28. August 1970, hrs. J. Hermann und K. Otto, Band III, Berlin, 183-187.

Boessneck, J. 1969. Osteological Differences between Sheep (Ovis aries Linn.) and Goat (Caprahircus Linn.), in Brotwell, D., Higgs, E., (eds.), Science in Archaeology, London, Thames and Hudson, pp. 331-358.

Brmbolić, M. 1996. The Khuman Belt from the Area of Tomaševac. Starinar XLVII, 273-277.

Гарашанин, М., Гарашанин, Д. 1958. Ископавање тумула у Белотићу и Белој Цркви. Зборник Народног музеја Београд I, 17-50.

Grant, A. 1982. The use of tooth wear as a guide to the age of domestic ungulates, in Wilson, B., Grigson, C., Payne, S. (eds.) Ageing and Sexing Animal Bones from Archaeological Sites, British Archeological Reports British Series 109. Oxford, BAR, pp. 91-108.

Dobney, K., Reily, K. 1988. A method for recording archaeological animal bones, the use of diagnostic zones. Cicaea V, 79-96.

Dreisch, A. 1976. A Guide to the Measurements of Animal Bones from Archaeological Sites. Cambridge, Mass., Harvard University Peabody Museum.

Ерцеговић-Павловић, С. 1967. Прилог проучавању средњовековних некропола у источној Србији, Старинар XVII, 143-150.

Ерцеговић-Павловић, С. 1979. Средњовјековни накит од украсних плочица, Зборник Народног музеја IX-X, 279-283. 
Ерцеговић-Павловић, С. 1986. Средњовјековна насеља и некрополе у Бољетину и Хајдучкој Воденици, Ђердапске свеске, посебна издања 1, Београд: Археолошки институт.

Јанковић, М. 1975. Две средњовековне некрополе у источној Србији, Старинар XXIV-XXV: 227-240.

Јанковић, М. 2005. Београд и његова околина од IX до XI века, Годишњак града Београда LII: 1-13.

Марјановић-Вујовић, Г. 1984. Средњевековна Винча, у Д. Срејовић, Б. Стојановић, Н. Тасић, Д. Крстић, ур., Винча у праисторији и средњем веку. Београд: Српска академија наука и уметности, стр. 85-99.

Марјановић-Вујовић, Г. 1985. Врсте и типови накита XI и XII века из некропола у Србији, Зборник радова Народног музеја (Чачак) XV: 5-20.

Marjanović-Vujović G. 1979. Necropole medievale Vinča, Inventaria Archaeologica, fascicule 22 (Y 209-218).

Marjanović-Vujović, G. 1986. Vajuga - Pesak, Бердапске свеске III: 184-199.

Паровић-Пешикан, М. 1984. Љубичевац - Гламија. Извештај о археолошким истраживањима у 1980. години, Бердапске свеске II: 137-140.

Минић, Д. 1970. Средњовековна некропола на Великом Градцу код Доњег Милановца, Старинар XX: 233-247.

Минић, Д. 1978. Керамичке посуде као гробни прилози на средњовековним некрополама у Србији, Годишьак града Београда XXV: 87-92.

Минић, Д. 1984 Песача, античко утврђење и средњовековна некропола, Старинар XXXIII-XXXIV: 171-175.

Payne, S. 1973. Kill-off patterns in sheep and goats, the mandibles from Aşvan Kale. Anatolian Studies XXIII: 281-303.

Поповић, М. 2002. Липовац - трагови средњовековног властеоског боравишта. Саопштења XXXIV: 157-177.

Радичевић, Д. 2000 Средњовековно српско гробље на локалитету Гушевац у Мрчајевцима, Зборник радова Народног музеја (Чачак) 30: 61-109.

Радичевић, Д. 2004. Гробља VII-XV столећа уз десну обалу Дунава између ушћа Велике Мораве и ушћа Тимока. Непубликован магистраски рад одбрањен на Одељењу за археологију Филозофског факултета, Универзитет у Београду.

Радичевић, Д. 2008. Периодизација позносредњовековних некропола у Доњем српском Подунављу. Старинар LVIII: 197-212.

Радишић, М. 2014. Позносредњовековне појасне копче западног порекла на централном Балкану, Гласник Српског археолошког друштва XXX: 109-132.

Radosavljević-Krunić, S. 1986. Une necropole medievale a Ljubičevac у Ђердапске свеске III, ур. Владимир Кондић, 329-341. Београд: Археолошки институт.

Станојев, Н. 1989. Некрополе X-XV века у Војводини. Нови Сад: Археолошко друштво Војводине.

Тасић, Н. Н. 2015. Методологије и процедуре на археолошким ископавањима Винче, Београд, Досије студио. 
Tasić, N., Marić, M., Filipović, D., Penezić, K., Dunbar, E., Reimer, P., Barclay, A., Bayliss, A., Gaydarska, B., Whittle, A. 2016. Interwoven strands for refining the chronology of the Neolithic tell of Vinča - Belo Brdo, Serbia, Radiocarbon 58 (4): 795-831.

Ћоровић-Љубинковић, М. 1958. Досадашња ископавања у Брестовику, на локалитету Висока раван, Зборник Народног музеја I: 325-331.

Ćorović-Ljubinković, M. 1956 La nècropole slave de Brestovik. Rapport prèliminaire des fouilles en 1953-1954, Archaeologia Iugoslavica II: 131-137.

Halstead, P., Collins, P., Isaakidou, V. 2002. Sorting Sheep from Goats, Morphological Distinctions between the Mandibles and Mandibular Teeth of Adult Ovis and Capra. Journal of Archaeological Science 29: 545-553.

Шпехар, П., Стругар Бевц, Н. 2016. Батајница - Велика хумка, раномађарска некропола, Монографије 18, Београд: Музеј града Београда. 


\title{
Kristina Penezić
}

University of Novi Sad, BioSense Institute

\section{Dejan Radičević}

Department of Archaeology, Faculty of Philosophy, University of Belgrade

\section{Jelena Bulatović}

Laboratory of Bioarchaeology, Department of Archaeology,

Faculty of Philosophy, University of Belgrade

\section{Nenad Tasić}

Department of Archaeology, Faculty of Philosophy, University of Belgrade

\section{FIRST RESULTS OF RESCUE ARCHAEOLOGICAL EXCAVATIONS AT THE SITE OF BELO BRDO IN VINČA IN 2019}

\author{
Keywords: Vinča - Belo Brdo site, Sector K (Klizište = Landslide), \\ rescue excavations, medieval necropolis
}

This paper presents the preliminary results of recent fieldwork conducted in the part of the site of Vinča - Belo Brdo that is endangered by a landslide. In order to excavate the rich archaeological remains before the situation with the sediment movements worsens, rescue excavations took place in the second half of 2019. The focus of this campaign was to investigate the level of destruction of this part of the site, as well as to excavate the human remains from the medieval necropolis that represents the final phases of occupation at the site. Since the first excavations of Vinča in 1908, and especially in the early campaigns of 1911 and 1912, medieval material and presence of inhumations was noted in large numbers. Systematic excavations in the period 1978-1983 were, among other things, focused on the excavation of the necropolis. According to the material in the National museum in Belgrade that originates from the site of Vinča without any specific context, the chronological span of the necropolis was divided into four horizons, ranging, very widely, from the $8^{\text {th }}$ up to the $17^{\text {th }}$ century. Available documentation from these excavations shows the presence of three stratigraphic horizons. At the end of these excavations, the total number of inhumations was well over 1000. In 2011, the focus of research at the site was on the area endangered by the landslide. In a trench with dimensions of $4 \times 20$ metres, additional 71 graves were excavated, sometimes containing several burials.

During the 2019 campaign, a surface of $c a .250$ square meters was investigated, with 91 defined and documented graves that sometimes contained several burials. Contrary to the earlier excavations, the number of burials of ju- 
veniles is much higher. There were 36 juvenile and 59 adult burials. Among the burials, remains of three medieval ovens were discovered, and one of them was excavated (Oven 3). Up to now, no medieval structures were documented at Belo Brdo. Oven 3 contained two substructions with pottery sherds, stone and brick fragments. Pottery fragments originated both from prehistory and from the medieval period as well. Most of them could not be more precisely dated due to their small size, but those with ornaments could be dated into the period between the $9^{\text {th }}$ and $11^{\text {th }}$ century. As for small finds from the graves, they could be dated into the period of the $13^{\text {th }}$ and $14^{\text {th }}$ century. The most notable one is a bronze belt found in situ. The horizon with ovens is older than the inhumations, as shown not only by the material but also by Grave 87 cutting and damaging Oven 3 . The excavations stopped at the level of Neolithic burnt daub. Two Neolithic burnt structures (houses) were detected, in the south-western and south-eastern part of the trench. Faunal remains from all contexts were analysed. Since most of the material originates from disturbed layers due to recent gardening, vegetation and landslide, the distribution of various animal taxa was documented only for Sector K. 